\title{
Quality Of Financial Statements And Its Effects On Received Credits For Small Medium Enterprise (SME's) Indonesia
}

\author{
Inayah Adi Sari, Dien Noviany Rahmatika, Aminul Fajri, and Ibnu Muttaqin
}

\begin{abstract}
This study examines the effect of the quality of financial statements, age, guarantees, and terms of SMEs on the level of credit received. This study uses primary data by distributing questionnaires to SME business respondents in the area of Tegal City, Brebes Regency, and Tegal Regency. The sample used was 90 respondents. The results of this study indicate that the quality of SME financial statements does not affect the amount of credit received, this is due to the still low quality of SME financial reports so that banks still doubt the relevance and reliability of the quality of their financial statements. While the age, colateral and term variables affect the amount of credit received by SMEs.
\end{abstract}

Index Terms-Quality Of Financial Statements, Age, Collateral, SME Terms, Credit.

\section{INTRODUCTION}

Small and Medium Enterprises (SMEs) are proven to be able to contribute to the Indonesian economy. In 2018, the realization of the contribution of SMEs to the National GDP reaches around $60.34 \%$. Minister of Finance Sri Mulyani Indrawati said that SMEs are an important element for the Indonesian economy, because until 2018 SMEs were able to absorb $96 \%$ of the workforce.

In 2018, there were 58.9 million SME units in Indonesia spread throughout Indonesia. By the end of 2019 it is predicted that the number of SMEs will grow by $5 \%$. The large number of SMEs reflects the potential for the development of SMEs to be able to contribute more to the Indonesian economy. SMEs are proven to be able to survive the 1997-1998 economic crisis and the 2008 global economic crisis.

In some countries, SMEs contribute quite a lot to the country's development. Recorded the number of SMEs in developed countries an average of $90 \%$ of the total business units, and absorbs $2 / 3$ of the workforce from the number of unemployed (Baas and Schrooten 2006). South Africa is a country with $95 \%$ of the business sector being SMEs. This sector annually contributes an average of $35 \%$ to gross domestic product, and is able to reduce as much as $50 \%$ the level of unemployment in the country (Zimele, 2009). The large potential of these SMEs is often constrained by capital problems to develop businesses.

The problem faced by SMEs in developing their business is capital. There is a SME financing program run by the

Published on February 26, 2020.

Authors are from University Pancasakti Tegal, Indonesia.

( corresponding email: inayahadisari@gmail.com). government. One such program is the People's Business Credit (KUR) which in 2019 is targeted to be around Rp 140 trillion. The purpose of the KUR is to be an effective capital financing solution for SMEs, because so far many SMEs have been constrained by access to banks to obtain financing (Osa, 2010). But the realization of the KUR was far from the target of only Rp 120 trillion.

The KUR distribution target has not yet been achieved because the banks appointed as KUR distributors are very careful in lending, because banks do not get information related to the condition of SMEs. The majority of SME entrepreneurs are unable to provide accounting information related to their business conditions. The more satisfied with the information received from SMEs, the easier it will be for banks to provide capital assistance. Finally, from a bank perspective, Moro and Fink (2013) conclude that SMEs who enjoy a high level of trust from loan managers get more credit and are less likely to be financially constrained. The trust given to SMEs comes from the completeness of information obtained by banks, not because of good relations between SMEs and banks. This is consistent with what was concluded by Ortiz and Molina (2006), that there is no relationship between loans provided with close relationships between banks and SMEs.

With an adequate understanding of accounting, SME entrepreneurs can meet the requirements in applying for credit, such as preparing financial reports (Warsono, 2009). Due to a lack of knowledge about accounting, the complexity of the accounting process and SMEs' perceptions of financial statements make the accounting process difficult (Said, 2009). Various other limitations faced by SMEs are the educational background of noneconomic owners, lack of discipline in carrying out accounting records, and the unavailability of sufficient funds to use accountant services or purchase accounting software to facilitate accounting bookkeeping.

In order to assist SMEs in meeting their financial reporting needs, the Indonesian Institute of Accountants Financial Accounting Standards (DSAK IAI) in 2016 has compiled and ratified Financial Accounting Standards for Micro and Small Entities (SAK EMKM). The SAK EMKM is effective as of January 2018 but application before the effective date is allowed. The use of SAK EMKM is intended for micro, small and medium entities without significant public accountability.

Based on this description, it is necessary to conduct research on whether the quality of the report, age, collateral, 
and terminology influences the amount of credit approved by the bank.

\section{LITERATURE REVIEW}

In managing their businesses, SMEs only record the amount of goods bought and sold, and the amount of debt / receivables. The recording is not in accordance with the format desired by the banking sector as the provider of funds (Jati, 2004). Using administrative staff to carry out accounting records is also an obstacle for SMEs because it is associated with costs incurred. The condition of SME credit expansion reached IDR 95,704.7 billion (2018) higher than in 2017 which was only IDR 89,987.8 billion or an increase of $6.35 \%$. This shows the high level of bank lending to SMEs.

In the research of Baas and Schrooten (2006) that bank lending to SMEs uses Soft Information \& Hard Information. Soft Information uses the Relationship Lending technique, namely bank lending to entrepreneurs based on good relations that have been established. Hard information includes using: 1) Financial Statement Lending, which uses information from financial statements that have been prepared in accordance with applicable accounting standards, 2) Assets Based Lending, namely using information related to controlled assets that are used as collateral, 3) Credit Scoring, the use of statistical techniques using financial data from financial statements and also the creditworthiness and background of the SME owners to be ranked. The opinion of Baas and Schrooten (2006) that the obstacle faced by most entrepreneurs in the world is the problem of getting bank credit. One reason is the lack of information that can be provided by SMEs to external parties. The advice given in the research is the importance of accounting standards that are able to accommodate the needs of SME entrepreneurs, in order to help SMEs in providing higher quality financial information.

Cziráky et al. (2005) examined the factors that influence SME lending in Croatia. The distribution of SME loans carried out by the Croatian government turned out to be low, even though the government had provided subsidies to the interest rates and the supply of funds that were considered to be sufficient for the credit needs of SMEs. The results of this study indicate that the banking average is inconsistent in terms of using credit approval criteria. The inconsistency is due to the condition of human resources related to expertise and knowledge in credit assessment in the country. There is a preference from banks to better approve the provision of small amounts of credit and for smaller companies that are classified as safer. This condition occurs because banks are classified as risk averse due to lack of information in the credit assessment process.

\section{FRAMEWORK}

\section{A. The Influence of Statement Financial Quality on Received Credits for Small Medium Emtreprise (SME's)}

Bornheim and Herbeck (1996) mentioned factors that could influence the relationship between banks and SME entrepreneurs, among others: in terms of banking in the form of debtor information availability, competition between banks, and product promotion costs, while in terms of SME entrepreneurs factors affecting relations with banks, it can be in the form of collateral, access to credit, and the cost of capital for the choice to make a loan, which can be seen from the amount of loan interest applicable.

Jati et al. (2004) stated that at present most SMEs still do not hold accounting books and reporting properly. The implementation of accounting books to provide informative financial reports is still difficult for SMEs. This is due to limited knowledge in accounting books, the complexity of the accounting process, and the assumption that financial statements are not important for SMEs (Said 2009). Maseko and Manyani (2011) also found that the majority of SMEs in Zimbabwe did not have complete accounting records because of limited accounting knowledge.

According to Baas and Schrooten (2006) that the most widely used consideration of granting credit is the financial statement lending, namely lending based on financial information from the debtor. Though the condition of SMEs was apparently not able to provide financial reports in accordance with banking needs. Cziráky et al. (2005) stated that the cause of the low level of SME lending is that banks do not have enough information in conducting credit worthiness assessments. Both of these studies reinforce that financial statements have an important role as a means of information for banks to assess the eligibility of credit.

H1: The quality of financial statements affects the amount of bank credit received by SMEs

\section{B. The Influence of Age on Received Credits for Small Medium Emtreprise (SME's)}

In addition to the quality of financial statements, other factors that influence the amount of lending received by SMEs are the age of the company as well as being one of the factors that influence SMEs to obtain credit from banks. The longer the company stands means the more mature the company in managing its business. So it will be easier to get bank credit than a young company that has just started, because it is more likely to experience a business failure (Cressy 2006). Bhaird and Lucey (2010) stated that newly established companies had difficulty obtaining bank credit, due to the asymmetry problems that arose related to the bank having never distributed credit to the company.

$\mathrm{H} 2$ : Business age has a positive effect on the amount of bank credit received by SMEs

C. The Influence of Collateral on Received Credits for Small Medium Emtreprise (SME's) 
Baas and Schrooten (2006) stated SMEs with small business sizes often have limited assets to be used as collateral for credit. Whereas one of the information used by banks in the decision to extend credit is to use information related to assets used as collateral (Assets Based Lending). SMEs that have assets to be used as collateral for credit will be more likely to get credit from banks.

H3: The amount of collateral has a positive effect on the amount of bank credit received by SMEs

\section{The Influence of Terms on Received Credits for Small Medium Emtreprise (SME's)}

Research conducted by Kirschenmann and Norden (2010), regarding the relationship between debtor risk and the credit period for loans provided by banks to small businesses concluded that there is a positive relationship between debtor risk and the loan period given by banks. This means that the longer the credit period, the higher the loan risk. It is therefore assumed that the term (credit term) will negatively affect the amount of credit provided by banks to SME entrepreneurs.

H4: Credit term has a positive effect on the amount of bank credit received by SMEs

Based on the explanation that has been described, the framework in the form of a research paradigm is as follows:

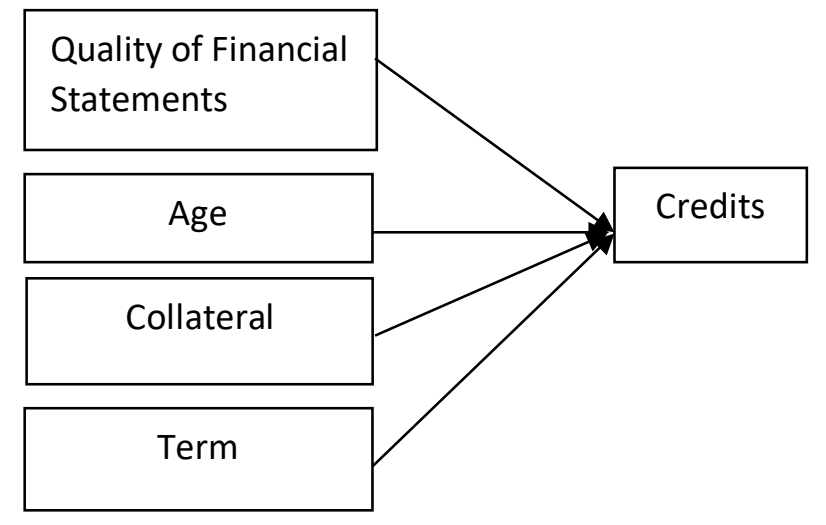

\section{RESEARCH METHODS}

Here is a research model:

CREDITS $=\beta 1+\beta 2$ REP-QUAL $+\beta 3$ AGE $+\beta 4$ CLTR + $\beta 5$ TERM $+\mathrm{e} 1$

Information:

CREDITSZ : the amount of credit received by SMEs

AGE : Long standing business

REP_QUAL : quality of financial statements

UKM. CLTRL: guarantees given related to credit applications.

$\begin{array}{ll}\text { TERM } & : \text { credit term or credit term } \\ \text { e } & : \text { error }\end{array}$

A. Amount of credit received by SMEs (CREDITSZ)
Points awarded for the answer to this question are 1 for credits less than Rp 10,000,000, 2 for (Rp 10,000,000 - Rp 25,000,000), 3 for $R p$ 25,000.00 - Rp 50,000,000, 4 for $R p$ $50,000,000-\mathrm{Rp} 100,000,000$, and 5 for loans of more than Rp 100,000,000.

\section{B. Quality of SME Financial Reports (REP_QUAL)}

Index of the quality of financial statements is assessed based on:

1. The SME performs accounting accounting or not, if you answer "Yes" then get points 1 , and 0 for the answer "No".

2. There are sections or divisions or special employees in the company that are responsible for accounting and financial reporting, point 1 is given if answering "Yes" and 0 for the answer "No".

3. There is accounting software that supports bookkeeping, point 1 is given if answering "Yes" and 0 for the answer "No"

4. Initial financial statements were first made Value is given according to the number of years from the beginning of the financial statements made until 2019.

5. Routine or not accounting transactions and financial reporting are made, if the answer "Routine" gets points 1 and 0 for the answer "No".

6. Accounting standards used, if you answer the answer choices "PSAK", or "Taxation Rules" or "Other" get point 1 , and point 0 for the answer "Don't Know".

7. Components of financial statements that will be made (there are 5 components of financial statements). Can answer more than 1 choice and each choice has 1 point, with a maximum point of 5 . Points earned from each Points obtained from each of these questions are added up so that they get an index number of the quality of financial statements.

\section{Operating Age (AGE)}

The length of the establishment of the business becomes an assessment of a business both by banks and investors, because from the age of this business can be known the business stage of the business along with the track record of the business undertaken so far. (Value 1 is given if the business life is 1 year, then 2 for the business life stands between 1-3 years, and 3 for more than 3 years)

\section{Credit Guarantee (CLTRL)}

Represents the value of the assets of the entrepreneur which is used as collateral in the credit application. Points awarded for the answer to this question are 1 if there are no guarantees, 2 for guarantees of less than IDR 10,000, 3 for IDR $10,000,000$ - IDR 25,000,000, 4 for IDR 50,000,000 IDR $100,000,000$, and 5 for more from Rp 100,000,000.

\section{E. Credit Term (TERM)}

Represents a period of time given to SMEs to be able to pay or repay their credit loans. The value given for the answer to this question is 1 for credit terms less than 1 year, 
2 for credit terms $>1$ year to 3 years, and 3 for credit terms more than 3 years.

\section{ANALYSIS OF RESULTS AND DISCUSSION}

The sample distribution based on business location is 90 respondents in the area of Tegal City, Tegal Regency and Brebes Regency. Based on the type of business carried out, the majority of respondents engaged in trading or buying and selling namely as many as 45 respondents, then 18 respondents engaged in business services, 26 respondents in manufacturing, and 11 respondents in agribusiness. If grouped based on business size, 35 respondents have a business that is classified as a micro business group, 43 respondents fall into the small business group, and 12 respondents belong to the medium business group. For respondents who had received bank credit were 78 respondents.

To see the relationship between variables, in Table 1 the correlation between variables is presented. Credit variable correlates most strongly with collateral. This gives an early indication that the variable that has a strong influence on the credit that is smashed by SMEs is the collateral variable. From the correlation table, there is no correlation between independent variables higher than 0.80 , so there is no indication of multicollinearity problems.

TABLE I CORRELATION COEFFICIENT CORRELATIONS ${ }^{\mathrm{a}}$

\begin{tabular}{llrrrrr}
\hline \multicolumn{7}{c}{ COEFFICIENT CORRELATIONS } \\
\hline Correlations & Credits & Rep Qual & Age & Cltr & Termin \\
\cline { 2 - 7 } & Credits & 1,000 &,- 043 &,- 119 &, 147 &,- 029 \\
\cline { 2 - 7 } & Rep_Qual &,- 043 & 1,000 &, 032 &,- 142 &, 761 \\
\cline { 2 - 7 } & Age &,- 119 &, 032 & 1,000 &,- 291 &,- 041 \\
\cline { 2 - 7 } & Cltr &, 147 &,- 142 &,- 291 & 1,000 &,- 056 \\
\cline { 2 - 7 } & Termin &,- 029 &, 761 &,- 041 &,- 056 & 1,000
\end{tabular}

The Determination Coefficient Test Model Summary ${ }^{\mathrm{b}}$

\begin{tabular}{|c|c|c|c|c|}
\hline & & & & \\
\hline Model & $\mathrm{R}$ & $\mathrm{R}$ Square & $\begin{array}{c}\text { Adjusted R } \\
\text { Square }\end{array}$ & $\begin{array}{c}\text { Std. Error of the } \\
\text { Estimate }\end{array}$ \\
\hline 1 &, $753^{\mathrm{a}}$ &, 566 &, 541 & 2,01188 \\
\hline
\end{tabular}

a. Predictors: (Constant), Credits, Rep_Qual, Age, Cltr, Termin b. Dependent Variable: Y

Based on the results of SPSS output in table II, it can be seen that the value of Adjusted R Square is 0.541. This means that the variability of the dependent variable can be explained by the independent variable of $54,1 \%$. While the remainder of $45,9 \%$ is explained by other factors not examined in this study such as caracter, condition SME"s and others.

\section{Simultaneous Test}

Simultaneous tests were assessed using the Anova Test.

TABLE III

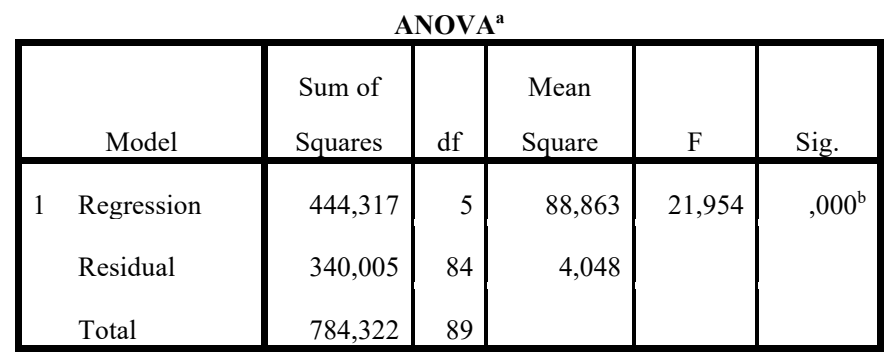

a. Dependent Variable: Y

b. Predictors: (Constant), Credits, Rep_Qual, Age, Cltr, Termin

Table III shows the Anova Test of Model Coefficients with a degree of freedom of 5. Significant values of 0.000 more small than $\alpha=0.05$. This means that the variables quality of financial statemen, age, collateral, and term together have a significant effect on the credit

\section{Hypothesis Test}

TABLE IV

\begin{tabular}{|c|c|c|c|c|c|c|}
\hline \multicolumn{7}{|c|}{ TABLE IV } \\
\hline & & \multicolumn{2}{|c|}{$\begin{array}{l}\text { Unstandardized } \\
\text { Coefficients }\end{array}$} & \multirow{2}{*}{$\begin{array}{c}\text { Standardized } \\
\text { Coefficients }\end{array}$} & \multirow[t]{2}{*}{$\mathrm{T}$} & \multirow[t]{2}{*}{ Sig. } \\
\hline & & $\mathrm{B}$ & $\begin{array}{l}\text { Std. } \\
\text { Error }\end{array}$ & & & \\
\hline \multirow[t]{6}{*}{1} & (Constant) & $-14,986$ & 3,999 & & $-3,747$ &, 000 \\
\hline & Rep_Qual &, 783 & ,382 & ,230 & 2,051 &, 053 \\
\hline & Age &,- 849 &, 195 &, 329 & 4,356 &, 000 \\
\hline & Cltr & 3,650 &, 553 & ,505 & 6,601 &, 000 \\
\hline & Termin & $-2,183$ & 1,004 & 242 & 2,173 &, 033 \\
\hline & Credits & ,963 &, 248 & ,284 & 3,891 &, 000 \\
\hline
\end{tabular}

The results of testing the model, can be seen in Table 2 . The variable quality of financial statement has a significance of 0.053 greater than $\alpha=0.05$. The resulting beta coefficient is 0,789 . This shows that the variable quality of financial statements (Rep Qual) of SMEs does not affect the amount of credit received (H1 rejected). This shows that UKM financial statements have not become a reliable and relevant source of information for banks. Baas and Schrooten (2006) state that one of the reasons for almost all SMEs in the world experiencing difficulties in obtaining bank credit is the limited quality of financial statement information in accordance with banking standards. The quality of financial statements that are classified as low, has become an obstacle for banks in assessing the performance of SME businesses. Based on research results, there are businesses that have been classified as quite large with a yearly business turnover of more than Rp. 200,000,000, but until now it is still very difficult to make financial reports. Although so far, many parties have provided accounting bookkeeping training, but due to limited understanding and time, accounting is not done regularly. Another obstacle experienced by SME 
entrepreneurs is the problem of not being diligent in keeping books, not having time, until the educational background is not derived from the accounting field.

If SME entrepreneurs want to employ special accounting staff or use special accounting software, for the majority of these alternative SMEs it is not yet the first choice, given the cost of hiring specialized staff or purchasing accounting software is still considered to be quite burdensome and not in accordance with the immediate benefits to be gained. The majority of SMEs have carried out a bookkeeping process, such as documenting transaction evidence such as receipts, receipts, invoices, and also have carried out a simple bookkeeping transaction process, as every sale of goods sold has been recorded in a special note. The majority of respondents stated the importance of accounting standards for SMEs that are able to help produce more informative information and can improve the quality of financial statements. They want an improvement in the quality of accounting and financial reporting currently available so that it provides greater benefits for the development of their business.

Variable age of business (Age) has a significant negative effect. It has a significance of 0.00 smaller than $\alpha=0.05$. The resulting beta coefficient is $-0,849$. This is different from the initial assumption that the length of the business standing has a positive effect on the credit received ( $\mathrm{H} 2$ rejected). These conditions indicate that the success of a business is not determined by how long the business has been established. So in providing credit, banks do not always look at the age of SMEs, because they are not necessarily mature SMEs with good business prospects. According to Anderson and Eshima (2011), younger companies are more likely to have a more flexible and reactive organizational structure than older companies, and also have a higher entrepreneurial nature. At the beginning of the establishment usually entrepreneurs may have to try to do various things (including keeping records neatly in order to know the progress of their business) in order to survive and improve their business going forward. The newly established company is also still at a stage with limited internal funding potential, thus requiring more access to external funding sources (Mazanai and Fatoki 2012).

Banks in the face of obstacles in accessing financial statements, often use soft information, such as assets-based lending (ie the size of assets owned by SMEs that can be used as collateral for credit). The variable collateral has a significant positive effect. It has a significance of 0.00 smaller than $\alpha=0.05$. The resulting beta coefficient is 3,65 . This is evident from the influence of the CLTRL (credit guarantee) variable on the amount of credit received by SMEs (H3 is not rejected). As for the credit term variable (TERM), it has a negative effect on the amount of credit received. The variable term has a significant negative effect.
It has a significance of 0.033 smaller than $\alpha=0.05$. The resulting beta coefficient is $-2,183$. This is likely due to the longer term credit will provide additional risks for the banks. The positive relationship between borrower risk and credit term is consistent with Kirschenmann and Norden (2010) research.

\section{CONCLUSION}

Based on the results of the testing and discussion described in the previous section, it can be concluded that the quality of the financial statements do not have a positive effect on the amount of credit received by SMEs. The quality of SME financial reports is still very low. The issuance of SAK EMKM is a hope to be able to improve the quality of SME financial reports to be better than currently available. Its implementation in 2018 still seems to encounter obstacles that are feared to hamper the implementation of this SAK. The biggest obstacle is the low understanding of SME entrepreneurs who will later use this SAK

Whereas age, collateral, and term have effect on the amount of credit received by SMEs. While the age of the business standing has a negative effect on the amount of credit received. Maybe because at the beginning of the stand the entrepreneurs tried to think about important things to do to improve their business going forward so that they had a better perception of the importance of bookkeeping and financial reporting. In the initial stage, entrepreneurs rely more on funding from external parties.

Banks in providing credit will be more confident if adequate asset collateral is available, so as to reduce the risk if there is a breakdown in repaying loans. Likewise with the term, the longer the credit period, the more risky it will be for the banks. This will certainly be a strong consideration for banks in disbursing loans to entrepreneurs.

The limitation in this study is the low understanding of respondents regarding the importance of bookkeeping for the development of their businesses, which has limited the ability of the research model to answer the hypotheses of the quality of fancial statements.

\section{REFERENCES}

Anderson, B.S. and Y. Eshima, "The Influence of Firm Age and Intangible Resources on the Relationship between Entrepreneurial Orientation and Firm Growth among Japanese SMEs". Journal of Business Venturing, vol. 28, issue 3, pp. 413-429, 2013.

Audretsch, D. B. and J.A. Elston, "Financing the German Mittelstand". Small Business Economics, 9, 97-110, February 1997.

Baas, T. dan M. Schrooten. 2006. "Relationship Banking and SMEs: A Theoretical Analysis". Small Business Economics, pp. 27, 2006.

Basri, Y.Z. and M. Nugroho. Ekonomi Kerakyatan: Usaha Mikro, Kecil, dan Menengah. Jakarta: Penerbit Universitas Trisakti, 2009.

Bornheim, S. and T.H. Herbeck. "A Research Note on the Theory of SME: Bank Relationship". Small Business Economic, 10, pp. 327-331, 1998.

Cziráky, D., S. Tiśma, and A. Pisarović, "Determinant of Low Approval Rate In Croatia”. Small Business Economic,25, pp. 347-372, 2005. 
Das, A.K. and N.B. Dey. (2005). Financial Management and Analysis Practices in Small Business: An Exploratory Study in India. Working Paper, http://sbaer.uca. edu/research/icsb/2005/paper53.pdf.

Ortiz, Hernan and Molina, "Lending To Small Busineses: the role of loan maturity in adressing information problems". Sauder School of Business The University of British Columbia, 2006.

Jati, H., B. Bala, dan O. Nisnoni. 2004. "Menumbuhkan Kebiasaan Usaha Kecil Menyusun Laporan Keuangan". Jurnal Bisnis dan Usahawan, II (8), 210-218, April 2004.

Kirschenmann, K. and L. Norden. 2010. "The Relation between Borrower Risk and Loan Maturity in Small Business Lending". Working paper. http:/terberger. bwl.uniannheim.de/fileadmin/images/ mitarbeiter/KirschenmannNorden/ Aug2010.pdf

Mac an Bhaird, C. and B.M. Lucey, "Determinants of Capital Structure in Irish SMEs". Small Business Economics, 35 (3), pp. 357$375,2010$.

Siregar, S.V., S.N. Harahap, dan Wasilah, Evaluasi Tantangan Penerapan Standar Akuntansi Entitas Tanpa Akuntabilitas Publik (SAK ETAP) untuk Usaha Kecil dan Menengah. Proposal Hibah RUUI, 2011.

Warsono, S. dan E. Murti, Akuntansi UMKMTernyata Mudah Dipahami dan Dipraktikkan. Yogyakarta: Asgard Chapter Winarno, 2010.

Zimele, A. 2009. The SMME Business Toolkit. New York: SBDA (Pty) Ltd.

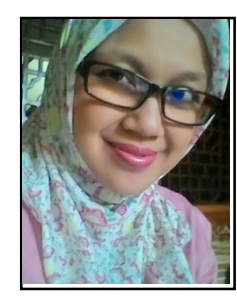

Inayah Adi Sari was born on November $23^{\text {th }}, 1978$ in Surakarta, Indonesia. She graduated from Muhammadiyah Surakarta University, Indonesia on 2002 and continued her post graduate in Jenderal Soedirman University, Purwokerto, Indonesia on 2011. She begin her career in Pancasakti University as a lecturer since 2008. Her major is accounting in Economic and Bussines Department. Her specialize is financial accounting.

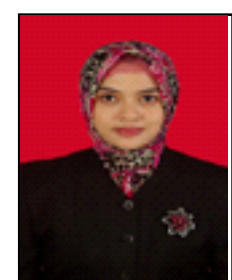

Dien Noviany Rahmatika was born on November $28^{\text {th }} 1975$ in Brebes, Indonesia. She is graduated from University of Diponegoro, Semarang, Indonesia in 1993 and continued her post graduate in Magister Management University of Gajah Mada, Jogjakarta, in 2001 and got Doctoral Accounting from Padjajaran University in 2017. Her major is accounting in Economic and Business Department. Dien is Dean of economic and business faculty in Pancasakti University, Tegal, Indonesia.

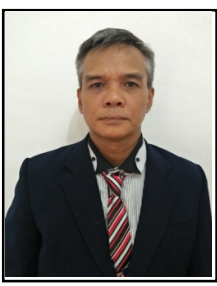

Aminul Fajri was born on March $2^{\text {nd }}, 1970$ in Sleman, Indonesia. He graduated from Gadjah Mada University, Indonesia on 2000 and continued his post graduate in Jenderal Soedirman University, Purwokerto, Indonesia on 2013. After finishing his education, he began his career as a lecture since 2004 in Pancasakti University Tegal Indonesia. Now he is a head of accounting studies program in economic and business faculty in Pancasakti University, Tegal, Indonesia. He specialize is financial accounting for practice and theory.

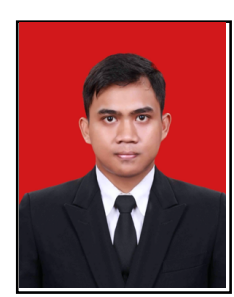

Ibnu Muttaqin was born on January $26^{\text {th }} 1992$ in Tegal, Indonesia. He graduated from Semarang State University, Semarang, Indonesia in 2013 and continued his post graduate in Diponegoro University, Semarang, Indonesia in 2016. His major is accounting in Economic and Bussinnes Department. After finishing his education, he began her career in Tegal. He began her career as a lecture since 2016 in Pancasakti University, Tegal, Indonesia. He teach financial accounting at his office. 